\title{
Efficiency of BJRI Kenaf-4 Yield Under Different Fertilizer Levels
}

\author{
Md. Saheb Ali, Md. Nasimul Gani, Md. Mahbubul Islam* \\ Agronomy Division, Bangladesh Jute Research Institute, Manik Mia Ave., Dhaka, Bangladesh \\ Email address: \\ mahbub_agronomy@yahoo.com (Md. M. Islam), csoagronomy@bjri.gov.bd (Md. M. Islam) \\ ${ }^{*}$ Corresponding author
}

To cite this article:

Md. Saheb Ali, Md. Nasimul Gani, Md. Mahbubul Islam. Efficiency of BJRI Kenaf-4 Yield Under Different Fertilizer Levels. American Journal of Agriculture and Forestry. Vol. 5, No. 5, 2017, pp. 145-149. doi: 10.11648/j.ajaf.20170505.12

Received: August 16, 2017; Accepted: August 31, 2017; Published: September 25, 2017

\begin{abstract}
The present study was conducted to clarify the fertilizer requirement on the growth and yield of the variety Bangladesh Jute Research Institute Kenaf-4. Consequently the experiment was conducted in Jute Agriculture Experimental Station, Manikganj and Jute Research Regional Station, Kishoreganj of Bangladesh Jute Research Institute. The results indicated significant effect of different NPKS levels on Bangladesh Jute Research Institute (BJRI) Kenaf-4 yield and yield contributing characters over control. The highest fibre $(3.14 \mathrm{t} / \mathrm{ha})$ and stick $(7.65 \mathrm{t} / \mathrm{ha})$ yield were obtained by the combination dose of $\mathrm{N}_{100} \mathrm{Kg} / \mathrm{ha}$ with PKS $10-60-20 \mathrm{~kg} / \mathrm{ha}$ at Kishoreganj. The plant height $(3.14 \mathrm{~m})$, base diameter $(19.47 \mathrm{~mm})$ also found highest with the same fertilizer treatment combination. By the same treatment produced higher fibre yield and yield contributing characters at Manikganj though that yield was slightly lower than Kishoreganj. Economic analysis suggested the best combination is $\mathrm{N}_{100} \mathrm{P}_{10} \mathrm{~K}_{60} \mathrm{~S}_{20} \mathrm{~kg} / \mathrm{ha}$. The findings of the present experiment clearly indicated a great prospect of nutrient combination of $\mathrm{N}_{100} \mathrm{P}_{10} \mathrm{~K}_{60} \mathrm{~S}_{20} \mathrm{~kg} / \mathrm{ha}$ on the growth and yield of fibre production on the variety BJRI kenaf-4.
\end{abstract}

Keywords: BJRI Kenaf-4, Fertilizer Requirements, Fiber Yield

\section{Introduction}

Bangladesh Jute Research Institute is the major organization of Jute and allied fibre crops research and Kenaf (Hibiscus cannabinus L.) is a promising fibre crop in Bangladesh $[1,2]$. It can be grown as an alternative crop of cotton that may be economically feasible to produce in Bangladesh [3]. Kenaf fiber used to make quality fine paper, as well as lower grade papers and cordage, also used to produce rope, canvas, sacking, carpet backing, fishing nets, interior automobile parts, such as door panels, headliners, animal bedding, and composite lumber substitutes [1]. Fertilizer application is necessary for high yielding Kenaf. There are many reports published on fertilizer requirement for kenaf production [4-19]. In Bangladesh farmers are not well known of better kenaf production technology that hinders the expected production of Kenaf and fibre and seeds are grown conventionally [20]. Poor fertilizer management practices also a cause for low yield of Kenaf. Therefore, the production of quality kenaf fibre in the country is very much essential to meet the increasing demand and expand this valuable crop. Taking into account all these essentials, upgrading of fiber yield and quality of Kenaf is the prime need of Bangladesh. In this aspect, research regarding development of new high yielding variety of Kenaf and determination of its fertilizer requirement is very important. Therefore, the present study has been undertaken to observe the effects of N, P, K and S fertilizers on the growth and yield of the pre-released Kenaf variety, BJRI Kenaf-4 and to find out the finest requirement of nutrients combination to obtain highest fibre production.

\section{Materials and Methods}

The experiment was set up at the Jute Agricultue Experimental Station (JAES) of BJRI, Jagir, under Sadar Upazila of Manikganj district and Regional Station, Kishoreganj of BJRI.

The experiment was laid out in randomized complete block design (RCBD) with three replications. A total 10 treatment combinations along with a control were distributed 
randomly in each plot as one replication (Table 1). The dimension of unit plots was $3 \mathrm{~m} \times 3 \mathrm{~m}$ having $1 \mathrm{~m}$ space between the plots, blocks and around the field. There was 20 $\mathrm{cm}$ deep drain around each block and plot. Each replication was divided into 10 unit plots. At the beginning of the experiment, the land was well prepared and fertilizers were applied as per treatment.

Table 1. Treatment combinations of $N, P, K$ and $S$.

\begin{tabular}{|c|c|c|c|c|}
\hline Treatment combinations & Nitrogen (kg/ha) & Phosphorus (kg/ha) & Potassium (kg/ha) & Sulfur (kg/ha) \\
\hline $\mathrm{T}_{1}: \mathrm{N}_{0} \mathrm{P}_{0} \mathrm{~K}_{0} \mathrm{~S}_{0}$ & 00 & 00 & 00 & 00 \\
\hline $\mathrm{T}_{2}: \mathrm{N}_{50} \mathrm{P}_{05} \mathrm{~K}_{30} \mathrm{~S}_{10}$ & 50 & 05 & 30 & 10 \\
\hline $\mathrm{T}_{3}: \mathrm{N}_{50} \mathrm{P}_{10} \mathrm{~K}_{60} \mathrm{~S}_{20}$ & 50 & 10 & 60 & 20 \\
\hline $\mathrm{T}_{4}: \mathrm{N}_{50} \mathrm{P}_{15} \mathrm{~K}_{90} \mathrm{~S}_{30}$ & 50 & 15 & 90 & 30 \\
\hline $\mathrm{T}_{5}: \mathrm{N}_{100} \mathrm{P}_{5} \mathrm{~K}_{30} \mathrm{~S}_{10}$ & 100 & 05 & 30 & 10 \\
\hline $\mathrm{T}_{6}: \mathrm{N}_{100} \mathrm{P}_{10} \mathrm{~K}_{60} \mathrm{~S}_{20}$ & 100 & 10 & 60 & 20 \\
\hline $\mathrm{T}_{7}: \mathrm{N}_{100} \mathrm{P}_{15} \mathrm{~K}_{90} \mathrm{~S}_{30}$ & 100 & 15 & 90 & 30 \\
\hline $\mathrm{T}_{8}: \mathrm{N}_{150} \mathrm{P}_{05} \mathrm{~K}_{30} \mathrm{~S}_{10}$ & 150 & 05 & 30 & 10 \\
\hline $\mathrm{T}_{9}: \mathrm{N}_{150} \mathrm{P}_{10} \mathrm{~K}_{60} \mathrm{~S}_{20}$ & 150 & 10 & 60 & 20 \\
\hline $\mathrm{T}_{10}: \mathrm{N}_{150} \mathrm{P}_{15} \mathrm{~K}_{90} \mathrm{~S}_{30}$ & 150 & 15 & 90 & 30 \\
\hline
\end{tabular}

Required amounts of N, P, K, S fertilizers were applied in the form of urea, TSP, MoP and gypsum. Urea was applied in two splits: half amount was applied at sowing and the rest half was top dressed at 45 DAS (days after sowing) while all other fertilizers were applied at the time of sowing. Kenaf seeds were broadcasted at the rate of $12 \mathrm{~kg} / \mathrm{ha}$. All cultural operations were done as and when necessary. The crop was harvested when $80 \%$ of the plants showed the sign of maturity. After shedding of leaves, the bundles were steeped plot-wise in pond water for 15-20 days for retting and fiber was extracted. At harvesting time, six plants were selected at random from each plot and tagged in the field to note plant height $(\mathrm{PH})$, base diameter (BD), fiber yield (FY) and stick yield (SY).

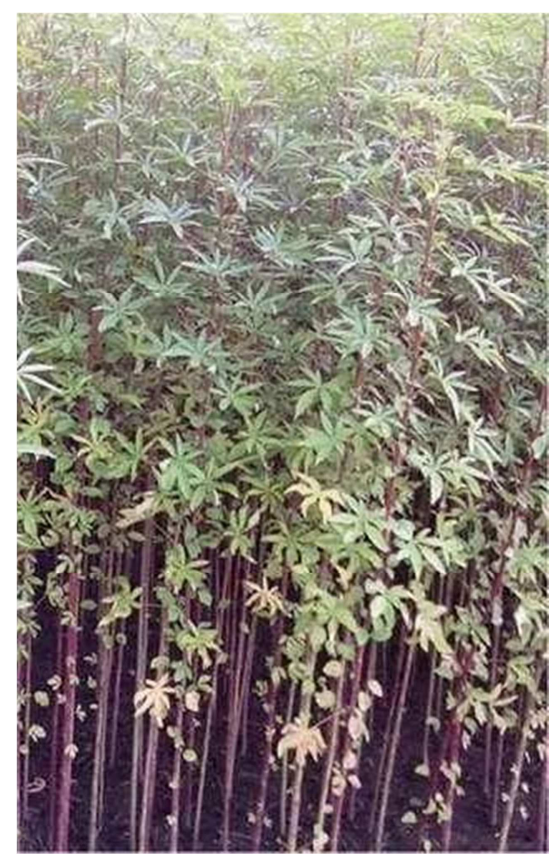

Figure 1. BJRI Kenaf-4 plant.

\section{Results and Discussion}

Results revealed that combined fertilizer doses focused the significant positive effect on the yield contributing parameters like plant height, base diameter, (Table $2 \& 3$ ). The yield and yield components i.e. plant height, base diameter, yield of fibre and stick were significantly increased over control by different rates of nitrogen. The highest dose of $\mathrm{N} 150 \mathrm{~kg} / \mathrm{ha}$ reduced the fibre yield (3.06t/ha) in compare to $\mathrm{N} 100 \mathrm{~kg} / \mathrm{ha}(3.13 \mathrm{t} / \mathrm{ha})$ at Kishoreganj. Results showed that $100 \mathrm{~kg} \mathrm{~N} / \mathrm{ha}$ is enough to produce the variety BJRI Kenaf-4. Incremental $\mathrm{N}$ doses enhanced the plant height and base diameter than control.

Phosphorus levels $(5,10$ and $15 \mathrm{~kg} / \mathrm{ha})$ were used in the experiment. The dose of P $10 \mathrm{~kg} /$ ha contributed significantly highest yield of fibre (3.13t/ha) and stick (7.65t/ha) (Table 3). In Kishoreganj, the longest plant $(3.14 \mathrm{~m})$ found with $\mathrm{P}$ $10 \mathrm{Kg} / \mathrm{ha}$ that was statistically identical with plant height found by $\mathrm{P} 15 \mathrm{Kg} / \mathrm{ha}$. Significantly highest base diameter (19.47mm) found also with P $10 \mathrm{Kg} /$ ha (Table 3).

The rate of potassium $0 \mathrm{~kg} / \mathrm{ha}, 30 \mathrm{~kg} / \mathrm{ha}, 60 \mathrm{~kg} / \mathrm{ha}$ and 90 $\mathrm{kg} / \mathrm{ha}$ were used to conduct this experiment. In Manikganj the rate $60 \mathrm{~kg} \mathrm{~K} /$ ha gave the highest plant height $(3.1 \mathrm{~m})$, base diameter $(19.16 \mathrm{~mm})$,) fibre $(3.03 \mathrm{t} / \mathrm{ha})$ and stick $(6.98 \mathrm{t} / \mathrm{ha})$ in compare to $90 \mathrm{Kg} / \mathrm{ha}$. Study noticed that the variety BJRI Kenaf-4, needs $\mathrm{K} 60 \mathrm{Kg} /$ ha to produce maximum yield.

All the treated plots with Sulphur increased the different growth parameters and yield of the variety BJRI Kenaf-4 over control. The highest rate of S $30 \mathrm{~kg} / \mathrm{ha}$ reduced the plant height. Maximum plant height $(3.14 \mathrm{~m})$ observed with $20 \mathrm{~kg}$ $\mathrm{S} /$ ha. Base diameter found the highest $(19.47 \mathrm{~mm})$ with a medium dose of S $20 \mathrm{~kg} \mathrm{~S} / \mathrm{ha}$. The yield of fibre $(3.13 \mathrm{t} / \mathrm{ha})$ and stick (7.65t/ha) achieved the highest with $20 \mathrm{~kg} \mathrm{~S} / \mathrm{ha}$ (Table 3). The study showed that combined dose of NPK and S 100-10-60-20 Kg/ha was a suitable dose for the cultivation of the variety BJRI Kenaf-4. 
Table 2. Results of nutrient combinations on growth and yield of thevariety BJRIKenaf-4 at JAES, Manikganj.

\begin{tabular}{lllll}
\hline Treatment (N-P-K-S kg/ha) & Plant height $(\mathbf{m})$ & Base diameter $(\mathbf{m m})$ & Yield of fibre (t/ha) & Yield of stick (t/ha) \\
\hline $\mathrm{T}_{1}: \mathrm{N}_{0} \mathrm{P}_{0} \mathrm{~K}_{0} \mathrm{~S}_{0}$ & $1.30 \mathrm{f}$ & $10.55 \mathrm{~d}$ & $1.10 \mathrm{f}$ & $3.17 \mathrm{e}$ \\
$\mathrm{T}_{2}: \mathrm{N}_{50} \mathrm{P}_{05} \mathrm{~K}_{30} \mathrm{~S}_{10}$ & $2.18 \mathrm{e}$ & $15.26 \mathrm{c}$ & $1.96 \mathrm{e}$ & $4.58 \mathrm{de}$ \\
$\mathrm{T}_{3}: \mathrm{N}_{50} \mathrm{P}_{10} \mathrm{~K}_{60} \mathrm{~S}_{20}$ & $2.19 \mathrm{de}$ & $15.66 \mathrm{bc}$ & $2.03 \mathrm{de}$ & $5.03 \mathrm{~cd}$ \\
$\mathrm{~T}_{4}: \mathrm{N}_{50} \mathrm{P}_{15} \mathrm{~K}_{90} \mathrm{~S}_{30}$ & $2.43 \mathrm{c}$ & $16.36 \mathrm{abc}$ & $2.38 \mathrm{~cd}$ & $5.26 \mathrm{bcd}$ \\
$\mathrm{T}_{5}: \mathrm{N}_{100} \mathrm{P}_{5} \mathrm{~K}_{30} \mathrm{~S}_{10}$ & $3.06 \mathrm{ab}$ & $17.16 \mathrm{abc}$ & $2.65 \mathrm{~b}$ & $6.58 \mathrm{abc}$ \\
$\mathrm{T}_{6}: \mathrm{N}_{100} \mathrm{P}_{10} \mathrm{~K}_{60} \mathrm{~S}_{20}$ & $3.1 \mathrm{a}$ & $19.16 \mathrm{a}$ & $3.03 \mathrm{a}$ & $6.98 \mathrm{a}$ \\
$\mathrm{T}_{7}: \mathrm{N}_{100} \mathrm{P}_{15} \mathrm{~K}_{90} \mathrm{~S}_{30}$ & $3.01 \mathrm{ab}$ & $19.11 \mathrm{a}$ & $2.93 \mathrm{ab}$ & $6.93 \mathrm{ab}$ \\
$\mathrm{T}_{8}: \mathrm{N}_{150} \mathrm{P}_{05} \mathrm{~K}_{30} \mathrm{~S}_{10}$ & $2.98 \mathrm{ab}$ & $19.06 \mathrm{a}$ & $2.9 \mathrm{ab}$ & $6.86 \mathrm{ab}$ \\
$\mathrm{T}_{9}: \mathrm{N}_{150} \mathrm{P}_{10} \mathrm{~K}_{60} \mathrm{~S}_{20}$ & $3.08 \mathrm{ab}$ & $19.04 \mathrm{a}$ & $2.93 \mathrm{ab}$ & $6.83 \mathrm{ab}$ \\
$\mathrm{T}_{10}: \mathrm{N}_{150} \mathrm{P}_{15} \mathrm{~K}_{90} \mathrm{~S}_{30}$ & $3.1 \mathrm{a}$ & $19.06 \mathrm{a}$ & $2.94 \mathrm{ab}$ & $6.78 \mathrm{ab}$ \\
$\mathrm{CV}(\%)$ & 4.95 & 5.08 & 4.75 & 6.42 \\
\hline
\end{tabular}

Table 3. Results of nutrient combinations on growth and yield of the variety BJRIKenaf-4 at Regional Station Kishoreganj.

\begin{tabular}{lllll}
\hline Treatment (N-P-K-S kg/ha) & Plant height (m) & Base diameter (mm) & Yield of fibre (t/ha) & Yield of stick (t/ha) \\
\hline $\mathrm{T}_{1}: \mathrm{N}_{0} \mathrm{P}_{0} \mathrm{~K}_{0} \mathrm{~S}_{0}$ & $1.38 \mathrm{e}$ & $11.81 \mathrm{f}$ & $1.07 \mathrm{f}$ & $3.54 \mathrm{f}$ \\
$\mathrm{T}_{2}: \mathrm{N}_{50} \mathrm{P}_{05} \mathrm{~K}_{30} \mathrm{~S}_{10}$ & $2.04 \mathrm{~d}$ & $14.32 \mathrm{e}$ & $1.88 \mathrm{e}$ & $5.1 \mathrm{e}$ \\
$\mathrm{T}_{3}: \mathrm{N}_{50} \mathrm{P}_{10} \mathrm{~K}_{60} \mathrm{~S}_{20}$ & $2.49 \mathrm{~cd}$ & $15.77 \mathrm{de}$ & $2.13 \mathrm{de}$ & $5.35 \mathrm{de}$ \\
$\mathrm{T}_{4}: \mathrm{N}_{50} \mathrm{P}_{15} \mathrm{~K}_{90} \mathrm{~S}_{30}$ & $2.61 \mathrm{bc}$ & $16.47 \mathrm{cde}$ & $2.38 \mathrm{cde}$ & $5.6 \mathrm{cde}$ \\
$\mathrm{T}_{5}: \mathrm{N}_{100} \mathrm{P}_{5} \mathrm{~K}_{30} \mathrm{~S}_{10}$ & $3.11 \mathrm{ab}$ & $17.18 \mathrm{bcd}$ & $2.68 \mathrm{bc}$ & $6.55 \mathrm{bc}$ \\
$\mathrm{T}_{6}: \mathrm{N}_{100} \mathrm{P}_{10} \mathrm{~K}_{60} \mathrm{~S}_{20}$ & $3.14 \mathrm{a}$ & $19.47 \mathrm{a}$ & $3.13 \mathrm{a}$ & $7.65 \mathrm{a}$ \\
$\mathrm{T}_{7}: \mathrm{N}_{100} \mathrm{P}_{15} \mathrm{~K}_{90} \mathrm{~S}_{30}$ & $3.09 \mathrm{ab}$ & $19.12 \mathrm{ab}$ & $3.08 \mathrm{ab}$ & $7.29 \mathrm{ab}$ \\
$\mathrm{T}_{8}: \mathrm{N}_{150} \mathrm{P}_{05} \mathrm{~K}_{30} \mathrm{~S}_{10}$ & $3.06 \mathrm{ab}$ & $18.92 \mathrm{ab}$ & $3.06 \mathrm{ab}$ & $7.45 \mathrm{ab}$ \\
$\mathrm{T}_{9}: \mathrm{N}_{150} \mathrm{P}_{10} \mathrm{~K}_{60} \mathrm{~S}_{20}$ & $3.11 \mathrm{ab}$ & $18.72 \mathrm{ab}$ & $3.08 \mathrm{ab}$ & $7.55 \mathrm{ab}$ \\
$\mathrm{T}_{10}: \mathrm{N}_{150} \mathrm{P}_{15} \mathrm{~K}_{90} \mathrm{~S}_{30}$ & $3.1 \mathrm{ab}$ & $19.07 \mathrm{ab}$ & $3.1 \mathrm{ab}$ & $7.6 \mathrm{ab}$ \\
$\mathrm{CV}(\%)$ & 5.33 & 4.86 & 5.15 & 5.61 \\
\hline
\end{tabular}

Study exposed that high dose of $\mathrm{K}(60 \mathrm{~kg} / \mathrm{ha})$ caused highest plant height and base diameter (Table 3). Some studies revealed that yield; Plant height and Base diameter increased with increasing rate of $\mathrm{K}$ dose [21-28].

Fibre yield and stick yield found significantly positive in trends of different treatments combinations for BJRI Kenaf 4 (Table 3). Highest fibre yield (3.13 t/ha) and stick yield (7.65 t/ha) were recorded with $\mathrm{T}_{6}\left(\mathrm{~N}_{100} \mathrm{P}_{10} \mathrm{~K}_{60} \mathrm{~S}_{20} \mathrm{~kg} / \mathrm{ha}\right)$ treatment, which was 192.52 and $116.10 \%$ higher than control (Calculated from Table 3). Based on Fibre yield among the treatments the treatment $\mathrm{T}_{6}$ can be ranked first and $\mathrm{T}_{1}$ for last position. The nutrient ratio is one of the key factors for kenaf production that is partially supported by previous report $[1,29]$.

Economic performance of a variety is a prime need for its cultivation and jute and allied fibre crops is not out of that. There are 1.2 million farmers are still directly connected with jute and allied fibre crops cultivation. Jute sector provides about $10 \%$ of total employment (production, transportation, processing and marketing) in the economy [30]. Therefore, economic analysis was made considering the variable cost of fertilizers, seeds, labor and price of fiber and stick (Table 4 \& 5). Result reveals that $\mathrm{T}_{6}\left(\mathrm{~N}_{100} \mathrm{P}_{10} \mathrm{~K}_{60} \mathrm{~S}_{20} \mathrm{~kg} / \mathrm{ha}\right)$ treatment was the most cost effective treatment as it gives the highest gross return with benefit cost ratio (BCR) which is highly profitable.
Table 4. Economics for var. BJRI Kenaf-4 at Manikganj.

\begin{tabular}{llll}
\hline Treatment & $\begin{array}{l}\text { Gross return } \\
\text { (Taka/hectare) }\end{array}$ & $\begin{array}{l}\text { Variable Cost } \\
\text { (Taka/hectare) }\end{array}$ & BCR \\
\hline $\mathrm{T}_{1}: \mathrm{N}_{0} \mathrm{P}_{0} \mathrm{~K}_{0} \mathrm{~S}_{0}$ & 51925 & 60750 & 0.854 \\
$\mathrm{~T}_{2}: \mathrm{N}_{50} \mathrm{P}_{05} \mathrm{~K}_{30} \mathrm{~S}_{10}$ & 89850 & 85930 & 1.045 \\
$\mathrm{~T}_{3}: \mathrm{N}_{50} \mathrm{P}_{10} \mathrm{~K}_{60} \mathrm{~S}_{20}$ & 93775 & 88760 & 1.056 \\
$\mathrm{~T}_{4}: \mathrm{N}_{50} \mathrm{P}_{15} \mathrm{~K}_{90} \mathrm{~S}_{30}$ & 108350 & 91590 & 1.182 \\
$\mathrm{~T}_{5}: \mathrm{N}_{100} \mathrm{P}_{5} \mathrm{~K}_{30} \mathrm{~S}_{10}$ & 122450 & 88030 & 1.391 \\
$\mathrm{~T}_{6}: \mathrm{N}_{100} \mathrm{P}_{10} \mathrm{~K}_{60} \mathrm{~S}_{20}$ & 138650 & 90860 & 1.526 \\
$\mathrm{~T}_{7}: \mathrm{N}_{100} \mathrm{P}_{15} \mathrm{~K}_{90} \mathrm{~S}_{30}$ & 134525 & 93690 & 1.435 \\
$\mathrm{~T}_{8}: \mathrm{N}_{150} \mathrm{P}_{05} \mathrm{~K}_{30} \mathrm{~S}_{10}$ & 133150 & 90130 & 1.477 \\
$\mathrm{~T}_{9}: \mathrm{N}_{150} \mathrm{P}_{10} \mathrm{~K}_{60} \mathrm{~S}_{20}$ & 134275 & 92960 & 1.444 \\
$\mathrm{~T}_{10}: \mathrm{N}_{150} \mathrm{P}_{15} \mathrm{~K}_{90} \mathrm{~S}_{30}$ & 134550 & 95790 & 1.405 \\
\hline
\end{tabular}

Table 5. Economics for var. BJRI Kenaf-4 at Kishoreganj.

\begin{tabular}{llll}
\hline Treatment & $\begin{array}{l}\text { Gross return } \\
\text { (Taka/hectare) }\end{array}$ & $\begin{array}{l}\text { Variable Cost } \\
\text { (Taka/hectare) }\end{array}$ & BCR \\
\hline $\mathrm{T}_{1}: \mathrm{N}_{0} \mathrm{P}_{0} \mathrm{~K}_{0} \mathrm{~S}_{0}$ & 51650 & 60750 & 0.850 \\
$\mathrm{~T}_{2}: \mathrm{N}_{50} \mathrm{P}_{05} \mathrm{~K}_{30} \mathrm{~S}_{10}$ & 87950 & 85930 & 1.023 \\
$\mathrm{~T}_{3}: \mathrm{N}_{50} \mathrm{P}_{10} \mathrm{~K}_{60} \mathrm{~S}_{20}$ & 98575 & 88760 & 1.110 \\
$\mathrm{~T}_{4}: \mathrm{N}_{50} \mathrm{P}_{15} \mathrm{~K}_{90} \mathrm{~S}_{30}$ & 109200 & 91590 & 1.192 \\
$\mathrm{~T}_{5}: \mathrm{N}_{100} \mathrm{P}_{5} \mathrm{~K}_{30} \mathrm{~S}_{10}$ & 123575 & 88030 & 1.403 \\
$\mathrm{~T}_{6}: \mathrm{N}_{100} \mathrm{P}_{10} \mathrm{~K}_{60} \mathrm{~S}_{20}$ & 144325 & 90860 & 1.588 \\
$\mathrm{~T}_{7}: \mathrm{N}_{100} \mathrm{P}_{15} \mathrm{~K}_{90} \mathrm{~S}_{30}$ & 141425 & 93690 & 1.509 \\
$\mathrm{~T}_{8}: \mathrm{N}_{150} \mathrm{P}_{05} \mathrm{~K}_{30} \mathrm{~S}_{10}$ & 141025 & 90130 & 1.564 \\
$\mathrm{~T}_{9}: \mathrm{N}_{150} \mathrm{P}_{10} \mathrm{~K}_{60} \mathrm{~S}_{20}$ & 142075 & 92960 & 1.528 \\
$\mathrm{~T}_{10}: \mathrm{N}_{150} \mathrm{P}_{15} \mathrm{~K}_{90} \mathrm{~S}_{30}$ & 143000 & 95790 & 1.492 \\
\hline
\end{tabular}




\section{Conclusions}

Each and every one of the treatments influenced on growth and yield. Among the treatment combination $\mathrm{N}_{100} \mathrm{P}_{10} \mathrm{~K}_{60} \mathrm{~S}_{20}$ $\mathrm{kg} / \mathrm{ha}\left(\mathrm{T}_{6}\right)$ treatment performed best for the most valuable yield parameters fiber and stick yield. We found highest benefit cost ratio from economic analysis and it was originated by the nutrient combination of $\mathrm{N}_{100} \mathrm{P}_{10} \mathrm{~K}_{60} \mathrm{~S}_{20}$ $\mathrm{kg} / \mathrm{ha}$. Bearing in mind all these aspects, especially yield and economics, $\mathrm{T}_{6}\left(\mathrm{~N}_{100} \mathrm{P}_{10} \mathrm{~K}_{60} \mathrm{~S}_{20} \mathrm{~kg} / \mathrm{ha}\right)$ treatment seems to be the best combination for fibre production of this variety (BJRI Kenaf-4).

\section{Conflict of Interest}

The authors declared no conflict of interest exist.

\section{References}

[1] Islam MM, Rahman MM (2008). In: Hand book on agricultural Technologies of Jute, Kenaf and Mesta crops. Bangladesh Jute Research Institute, Manikmia Avenue, Dhaka-1207, Bangladesh.

[2] Mollah MAF, Islam MM, Hossain MS, Rahman ML, Rahman MS (2015). Electrical conductivity, accelerated aging and field emergence tests of kenaf (Hibiscuss cannabinus L.) seed quality as affected by storage container and seed moisture content. Int. J. Sustain. Agril. Tech. 11(10):01-09.

[3] Scott AWJr, Taylor CS (1990). "Economics of Kenaf Production in the Lower RioGrande Valley of Texas." p. 292297. In (J. Janick and J. E. Simon, eds.) Advances inNew Crops. Timber Press, Portland, OR.

[4] Jie B, Defang L, Anguo C, Jianjun L, Siqi H, Huijuan T (2017). Evaluation of Nutritive Value of Seven Kenaf (Hibiscus cannabinus L.) Varieties Harvested Depending on Stubble Height. Pertanika Journal of Tropical Agricultural Science. 1:40(1).

[5] Taiwo AM, Gbadebo AM, Oyedepo JA, Ojekunle ZO, Alo OM, Oyeniran AA, Onalaja OJ, Ogunjimi D, Taiwo OT (2016). Bioremediation of industrially contaminated soil using compost and plant technology. Journal of hazardous materials. 304:166-72.

[6] Alexopoulou E, Li D, Papatheohari Y, Siqi H, Scordia D, Testa G (2015). How kenaf (Hibiscus cannabinus L.) can achieve high yields in Europe and China. Industrial Crops and Products. 68:131-40.

[7] Kipriotis E, Heping $X$, Vafeiadakis T, Kiprioti $M$, Alexopoulou E (2015). Ramie and kenaf as feed crops. Industrial Crops and Products. 68:126-30.

[8] Khalatbari AM, Jaafar HZ, Khalatbari AA, Balouei F (2015). Physical and histochemical fiber properties of kenaf (Hibiscus cannabinus L.) affected by different water treatments. Journal of Food, Agriculture \& Environment. 13(1):71-6.

[9] Bada BS (2015). Bioremediation of textile effluent polluted soil using kenaf (Hibiscus cannabinus Linn.) and composted market waste. Journal of Applied Sciences and Environmental Management. 19(4):773-6.
[10] Basri MH, Abdu A, Junejo N, Hamid HA, Ahmed K (2014). Journey of kenaf in Malaysia: A Review. Scientific Research and Essays. 9(11):458-70.

[11] Salih RF, Abdan K, Wayayok A (2014). Growth responses of two kenaf varieties (Hibiscus cannabinus L.) applied by different levels of potassium, boron and zinc. Journal of Agricultural Science. 6(9):37.

[12] Kang C, Choi W, Yoo Y, Choi K, Kim H, Song Y, Kim C (2014). The growth phase and yield difference of kenaf (Hibiscus cannabinus L.) on soil salinity in reclaimed land. Korean Journal of Crop Science/Hanguk Jakmul Hakhoe Chi. 59(4):511-20

[13] Salih RF, Abdan K, Wayayok A, Rahim AA, Hashim N (2014). Response of Nitrogen Content for Some Varieties of Kenaf Fiber (Hibiscus cannabinus L.) by Applying Different Levels of Potassium, Boron and Zinc. Agriculture and Agricultural Science Procedia. 1(2):375-80.

[14] Monti A, Alexopoulou E (2013). Kenaf: A Multi-Purpose Crop for Several Industrial Applications. London, UK: Springer.

[15] Lavu RV, De Schepper V, Steppe K, Majeti PN, Tack F, Du Laing G (2013). Use of selenium fertilizers for production of $\mathrm{Se}$ - enriched Kenaf (Hibiscus cannabinus): Effect on $\mathrm{Se}$ concentration and plant productivity. Journal of Plant Nutrition and Soil Science. 176(4):634-9.

[16] Basri MH, Abdu A, Jusop S, Ahmed OH, Abdul-Hamid H, Kusno MA, Zainal B, Senin AL, Junejo N (2013). Effects of mixed organic and inorganic fertilizers application on soil properties and the growth of kenaf (Hibiscus cannabinus 1.) cultivated on bris soils. American Journal of Applied Sciences. 10(12):1586.

[17] Tigka EL, Beslemes DF, Danalatos NG, Tzortzios S (2013). Evaluation of cover-cropping managements on productivity and N-utilization efficiency of kenaf (Hibiscus cannabinus L.), under different nitrogen fertilization rates and soil types. European journal of agronomy. 46:1-9.

[18] Lee J, Vijayanand V, Koo J, Ha B, Kim D, Kim J, Kim S, Kang S (2012). Comparison of growth characteristics and chemical composition of kenaf (Hibiscus cannabinus L.) varieties as a potential forage crop. Korean Journal of Crop Science/Hanguk Jakmul Hakhoe Chi. 57(2):132-6.

[19] Bahtoee A, Zargari K, Baniani E (2012). An investigation on fiber production of different kenaf (Hibiscus cannabinus 1.) genotypes. World Applied Sciences Journal. 16(1):63-6.

[20] Mollah MAF, Islam MM, Rahman MS, Tareq MZ, Haque SMA (2015). Yield and cost of kenaf seed production as influenced by planting date and method. Int. J. Sustain. Agril. Tech. 11(12): 01-06.

[21] Alam AKMM, Khandker S, Gani, MN, Ahmed SA (2000). Uptake addition and balance of nutrients under integrated fertilizer management in jute based cropping patterns. B. J. Sci. and Tech. 2(2):147-153.

[22] Alim MA (2003). Impact of $\mathrm{N}$ and $\mathrm{K}$ on soil properties and growth, yield and nutrient uptake of jute. M. S. thesis. BSMRAU, Salna, Gazipur. Bangladesh.

[23] Sarker AK, Bandopaddhay PK (2000). Effect of potassium, boron and crop age on the yield and quality of white jute (Corchorus capsularis). Indian Agr. 26:212-216. 
[24] Das KBG, Pathak D (1996). Response of Capsularis to potassium fertilization. Ann. Agril. Res. 17(2): 188-189.

[25] Sarkar SK, Ghosh RK, SoundaG, Maitra S, Rux DK, Ghosh K (1997). Effect of levels of nitrogen, potassium and soil moisture tension on growth, nutrient uptake and water use efficiency of jute. J. Interacademia 1(3): 183-188.

[26] Zheng ZH, Huang YX, Peng XJ (1984). Effects of additional $\mathrm{K}$ application to jute. China's Fiber Crops. No. 2. 14-15.

[27] Rafique ZA (2003). Yield performance of mesta (Hibiscus sabdariffa L.) as influenced by fertilizer and population levels. M. S. Thesis. Department of Agronomy, Bangabandhu Sheikh Muzibur Rahman Agricultural University, Salna, Gazipur, Bangladesh.
[28] Chew WY, Malek MAA, Ramli K (1982). Nitrogen and potassium fertilization of congo jute (Urena lobata) and kenaf (Hibiscus cannabinus) on Malaysian peat. MARDI-Res. Bulletin 10 (3): 317-322.

[29] Islam MM, Alam ATMM (2012). Agronomic Research and Advancement in Jute Crop in Bangladesh, (Sub-Theme Paper). Souvenir, 11th Conference on Advances in Agronomic Research under Changing Environment in Bangladesh. Held on October 6, 2012. At Bangladesh Agricultural Research Institute, Joydebpur, Gazipur-1701, Bangladesh. P-101.

[30] Islam MM (2013). Jute of Bangladesh: It's contribution to environment and challenges. The Reflector, Reflecting the issues and development in societies and states. Publisher: Md. Eanyet Ullah, 366 South Paikpara, Mirpur, Dhaka-1216, Bangladesh, 2(8): 08-10. 